\title{
RESEARCH ARTICLE LEAF ANATOMY AND MICROMORPHOLOGY OF SELECTED PLANT SPECIES IN COASTAL AREA OF KUANTAN, PAHANG, MALAYSIA
}

\author{
Che Nurul Aini Binti Che Amri*, Nurul Atiqah Binti Mohammad Mokhtar, Rozilawati Shahari \\ Department of Plant Science, Kulliyyah of Science, International Islamic University Malaysia, Jalan Sultan Ahmad Shah, Bandar Indera Mahkota, \\ 25200 Kuantan, Pahang, Malaysia. \\ *Corresponding author e-mail: chenurulainicheamri@iium.edu.my
}

This is an open access article distributed under the Creative Commons Attribution License, which permits unrestricted use, distribution, and reproduction in any medium, provided the original work is properly cited.

\section{ARTICLE DETAILS}

Article History:

Received 01 September 2019 Accepted 04 October 2019

Available online 17 October 2019

\section{ABSTRACT}

Plant anatomy can play vital role in plant taxonomy for successfully resolve taxonomic problems among different plant species. The anatomical studies of plant species living in coastal area of Kuantan, Pahang are scarce. Thus, the aim of this study was to identify the common, variation and diagnostic characteristics of leaf anatomy and micromorphology of selected plant species collected from Balok and Sepat beach area which can give additional information for identification of species. Four species studied namely Ipomoea pes-caprae (L.) R. Br., Calophyllum inophyllum L., Hibiscus tiliaceus L. and Stachytarpheta jamaicensis (L.) Vahl. Methods used were sectioning using sliding microtome, epidermal peeling and leaf micromorphology method using scanning electron microscope (SEM). The findings from this study showed that only three characteristics are similar among them which include the presence of collenchyma, sclerenchyma and mucilage cells or canals in either petiole or midrib of the leaves. Meanwhile, there are eight differences were observed which are types of stomata and trichomes, pattern of anticlinal wall and vascular bundles, type of epicuticular wax structures, cuticle ornamentations, size of epidermal cells and the presence of cell inclusions. The diagnostic characteristics identified in this study are closed-system of vascular bundle, presence of multicellular capitate glandular, 2-4 armed trichomes and 5-8 armed stellate trichomes and also flakes type of wax layers that can only be found in H. tiliaceus while 1:1 ratio size of epidermal cells can only be found in I. pes-caprae. The study reveals that leaf anatomy and micromorphology characteristics could be beneficial as an additional data for identification of species along the coastal area of Kuantan, Pahang.

\section{KEYWORDS}

Plant anatomy, leaf micromorphology, Ipomoea pes-caprae, Calophyllum inophyllum, Hibiscus tiliaceus, Stachytarpheta jamaicensis.

\section{INTRODUCTION}

Plant anatomy is very important in plant taxonomy as the anatomical characters of vegetative and floral parts of flowering plants can successfully solve taxonomic problems and for elucidation of phylogenetic relationship [1]. However, anatomical characters cannot form the basis of classification but as additional information to those external morphological characters on which classifications have been built [2]. Besides that, they also stated that anatomical studies are sometimes very helpful in identifying the fragmentary material which lacked flower and fruits in the herbarium specimens.

At the same time, plant anatomy is essential to the study of plant systematics, palaeobotany, evolutionary biology, physiology, ecology and science of developmental genetics [3]. Plant anatomy can also be applied to a wide range of fields such as plant pathology, plant breeding and wood technology. It is also important to identify the microscopic plant remains for forensics, archaeology and dating of historical antiquities [4]. Furthermore, anatomical information is required to further understand the characteristics of material like wood or fibers, the textual quality of food products or the ability of plant to resist insects or disease attacks [5]. The anatomical study of this research requires the need to understand the anatomy of the plant species that grow in the coastal area. Beaches and dunes are distributed in tropical and temperate coastal areas worldwide. Dunes are formed when waves deliver sand from the near-shore to the beach. The exposed sand dried by the sun is then transported inland by wind to form dunes. Dunes formation requires a source of sand usually carried from the beach by onshore winds and vegetation to trap and stabilize the sand [6].
The study regarding the sand dune plants live in the Bermuda Island shows that the leaf structure of plant live on that area has abundance of palisade layers on the upper and under sides of the leaves [7]. However, anatomical studies on plant species in Malaysia coastal area are still not wide. Thus, the aim of this study and identify the leaf anatomy of different plant species located in the coastal area of Kuantan, Pahang.

\section{MATERIAL AND METHODS}

\subsection{Plant materials}

Four species were selected from Balok and Sepat Beach Area in Kuantan, Pahang namely Ipomoea pes-caprae, Hibiscus tiliaceus, Calophyllum inophyllum and Stachytarpheta jamaicensis. Leaf specimens were compressed and dried in the oven under laboratory conditions. Then, the voucher specimens were deposited in International Islamic University Malaysia Herbarium for future reference.

\subsection{Light microscopy}

The leaf parts taken for analysis were mature leaves and fixed in AA solution (Acid acetic: Alcohol in a ratio of 1:3). Parts of petioles, midribs, leaf lamina and margin were sectioned in a range of thickness (15-40 $\mu \mathrm{m})$ using a sliding microtome and stained in Safranin and Alcian blue. Slides were mounted in Euparal after dehydration. Images were captured using a video camera (JVC) attached to a Leica ICC50 HD Microscope. Permanent slides were prepared, observed under a light microscope with an attached digital camera. Descriptions of leaf anatomical characteristics were documented accordingly [8]. 


\subsection{Scanning electron microscopy}

Small pieces of leaves were cut from the same area of the leaf lamina, affixed to aluminium stubs with double sided adhesive tape and then sputter-coated with a thin film of gold to improve the electrical conducting properties of the leaf surface. The critical point drying and gold coating was done as follows; samples were dried in a critical point drier and mounted on aluminium stubs. Samples were gold-coated using a sputter coater and examined under a scanning electron microscope Zeiss Model EVO 50.

\section{RESULTS AND DISCUSSION}

The findings of this study have shown that there are three similarities in leaf anatomical and micromorphological characteristics in four plant species studied (Figure 1). Previous research recorded mucilage cells have considerable taxonomical value for the identification of species [9]. From this study, all the species have mucilage cells or canals in either petiole or midrib. The mucilage cells in I-pes-caprae, the midrib of $H$. tiliaceus and $S$. jamaicensis can be found in parenchyma cortex while mucilage cells of petiole of $H$. tiliaceus are present in both parenchyma cortex and vascular bundle. Meanwhile, $C$. inophyllum has mucilage canals in parenchyma cortex. This finding supports the study conducted by certain group researchers that the presence of mucilage cells and canals have some taxonomical value to identify species $[10,11]$.

Sclerenchyma cells consist of collection of cell types with thickened secondary walls lignified when mature [4]. All species in this study have sclerenchyma cells in midrib and petiole with densely or sparsely scattered around the vascular bundle. This may be due to the exposure of strong wind as sclerenchyma cells provide support to the plant body [4]. The number of collenchyma layers has been reported to have high significant in taxonomic value for identification of species. This has been proved by a study on two species of Datura innoxia and D. stramonium [12]. However, this finding shows that all the species studied contain collenchyma cells in abaxial and adaxial leaf surfaces in both petiole and midrib. The collenchyma cells in $S$. jamaicensis have been found from previous study conducted [13]. The presence of collenchyma cells in all species studied perhaps due to the support needed to withstand the strong wind along the coastal region.

This study also reported that there are nine characteristics that can be used to differentiate between the four species studied. The characteristics are presence of cell inclusion, type of trichomes, stomata and wax, type of epicuticular ornamentations and anticlinal walls, size of epidermal cell and pattern of vascular bundles (Figure 2). Most plants accumulate inorganic inclusions called calcium oxalate crystals in both vegetative and reproductive organs. It was reported that these crystals are present in more than 215 higher plant families including gymnosperm and angiosperm. They can be classified into various types based on their morphology. For this reason, crystal distribution and shape have been used as taxonomical character for some plant taxon. The result from this study showed that there is one type of crystal that can be found which is crystal druses. Crystal druses can be found in all species except in I. pescaprae. Most of the druses are located in parenchyma cortex in petiole or midrib of the species studied.

Trichomes have taxonomical value for the determination of species or genera [9]. This is supported by a previous study on various Parashorea species where they found that all Parashorea species possess simple unicellular trichome [14]. This type of trichomes can be long or short, has either thick walls with narrow lumen or less thickened walls and a wider lumen. Moreover, there are also tufted trichome present in all species studied except in P. lucida and P. parvifolia. The result from this study shows that there are several types of trichomes that have been identified in the species studied except in C. inophyllum which are peltate glandular, multicellular capitate glandular, stellate, unicellular and uniseriate as well as 2-4 armed trichomes (Figure 2). Stomatal types also can be of taxonomical value to identify species [9]. There was a study conducted to observe six type of stomata in 69 dicot species consists of 64 genera and 28 species identified which are anomocytic, paracytic, diacytic, parallelocytic, cyclocytic and anisocytic [15]. In this study, stomata present in I. pes-caprae and S. jamaicensis are amphistomatic (stomata occur in adaxial and abaxial leaf surface) while $C$. inophyllum and $H$. tiliaceus are hypostomatic, (stomata are in abaxial leaf surface only). Moreover, only I. pes-caprae possess two types of stomata (heterostomatic) which are paracytic and anisocytic with elliptical shape while other species have only one type of stomata either paracytic or diacytic.

A study has proved that the pattern of anticlinal walls have some taxonomic significance to differentiate Avicennia species from other Acanthaceae taxa studied [16]. They found that all Avicennia species possess wavy to sinuous anticlinal walls while Strobilanthes crispa and Asystasia gangetica subsp. micrantha showed sinuous anticlinal walls. In this study, it showed that there are two patterns of anticlinal walls observed which are straight to wavy and sinuous. Straight to wavy anticlinal walls were identified in abaxial and adaxial surface of $I$. pes caprae and $H$. tiliaceus while sinuous anticlinal walls were observed in abaxial and adaxial surface of $C$. inophyllum and $S$. jamaicensis. This finding supports the previous study that found the epidermal cells of $S$. jamaicensis are mostly sinuous, occasionally arched or straight [17]. Hence, variations in anticlinal walls are useful to identify species. Besides that, several types of waxes are also identified in the leaves of five selected taxa in the genus of Schoutenia Korth [18]. This study has found that there are five types of waxes present on abaxial and adaxial epidermis in all species studied. The types of waxes are film layer, granular coatings, verrucate, crust and flakes of wax layers as mentioned in Table 1.

This study has identified that the epidermal cell outlines of I. pes-caprae, $S$. jamaicensis and adaxial of $H$. tiliaceus can be distinguishable because anticlinal wall slightly raised into ridges. Meanwhile, the epidermal cell outlines of $C$. inophyllum and abaxial of $H$. tiliaceus cannot be differentiated. This study supports previous research which found the presence of different types of cuticle ornamentations on adaxial and abaxial epidermal cells of several species of Acanthaceae [19]. Cuticle ornamentation can provide additional information because it has taxonomical value to identify species [18]. They identified three patterns of cuticle ornamentation in selected plant species of Schoutenia. Thus, cuticle ornamentation is one of the characteristics that can contribute to the identification of species. The ratio of height to width epidermal cell at midrib and petiole is observed to see the variation among species studied. It was found that all species have ratio of epidermal cell length to width of $1: 2$ except in the midrib of $I$. pes-caprae with ratio of $1: 1$. This study supports a research where they identified three ratios of $1: 1,1: 2$ and $3: 1$ in several species of Schoutenia [18]. This shows that size of epidermal cell can be used as an additional characteristic to differentiate the species.

Table 1: Morphology of Selected Plant Species in Coastal Area of Kuantan, Pahang

\begin{tabular}{|l|l|l|}
\hline \multirow{2}{*}{ Plant species } & \multicolumn{2}{|l|}{ Types of cuticular wax } \\
\cline { 2 - 3 } & Adaxial & Abaxial \\
\hline I. pes-caprae & Film layer, crust, granules \\
\hline C. inophyllum & $\begin{array}{l}\text { Verrucate, crust, } \\
\text { granules }\end{array}$ & Granules, crust \\
\hline H. tiliaceus & Verrucate, flakes, granules \\
\hline S. jamaicensis & Film layer, crust, granules \\
\hline
\end{tabular}
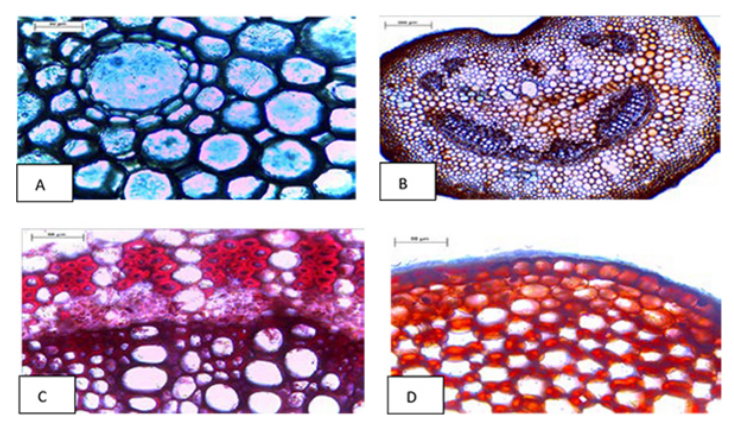

Figure 1: Common characteristics that have been found in all species studied. A) Mucilage canal in parenchyma cortex of $C$. inophyllum; B) Mucilage cells in petiole of I. pes-caprae; C) Sclerenchyma cells in $H$. tiliaceus and D) Collenchyma cells in I. pes-caprae.

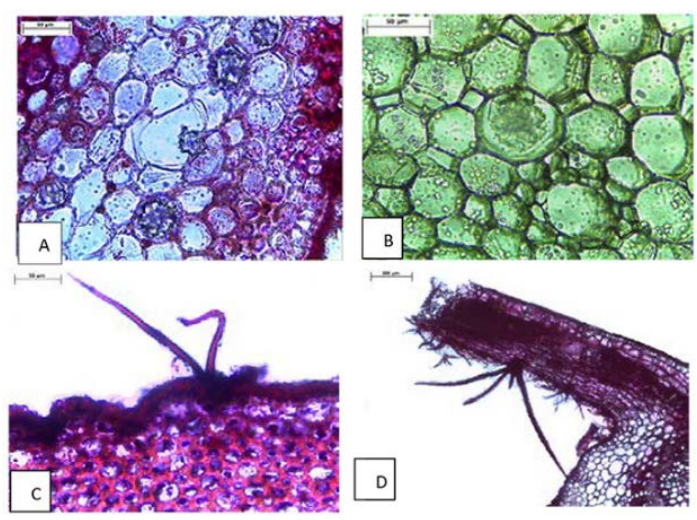



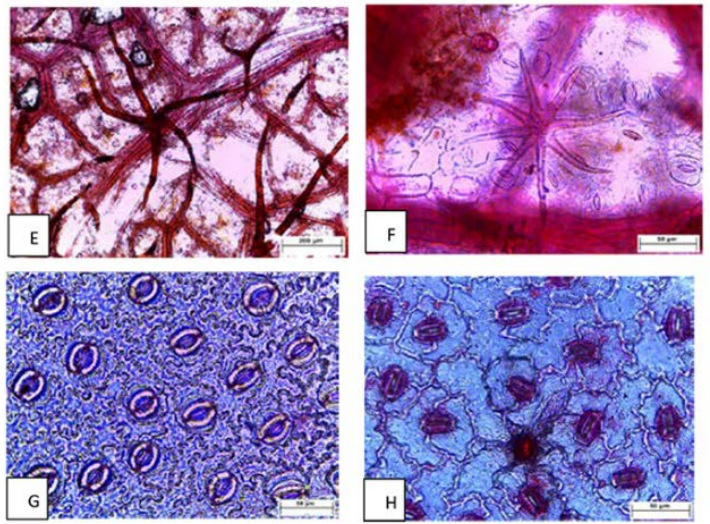

Figure 2: A \& B) Druses found in parenchyma cortex $H$. tiliaceus and $C$. inophyllum; C-F) Trichomes; G-H) Stomata at abaxial of epidermal cells in C. inophyllum and S. jamaicensis.

The result from this study showed the variation in pattern of vascular bundle in petiole of species studied (Figure 3). There are four types of pattern in petiole vascular bundle have been successfully identified (Table $2)$. According to a study, petiole vascular bundle has taxonomic value for identification of certain species and can be used for classification of different genera in family Dipterocarpaceae [20]. This finding is also support the study who discovered 11 types of petiole vascular bundle arrangement in several species of Microcos L [21]. Besides that, this study also discovered the variation in midrib vascular bundle arrangements in all the species studied (Figure 4) (Table 3). Midrib vascular bundle is also has important taxonomical value as Ekeke and Mensah identified several types of midrib vascular bundles in 14 genera of family Asteraceae [22]. They found that the number and arrangement of vascular bundle can be used for identification of species or genera. Furthermore, the variations in vascular bundle system, the shape and arrangement of main vascular bundles, presence of additional and medullary vascular bundles, position of additional vascular bundles and shape of medullary vascular bundles in selected medicinal plant species in Rubiaceae [23].

Table 2: Description of petiole vascular bundles for species studied

\begin{tabular}{|l|l|l|}
\hline Type of pattern & Description & Species \\
\hline Type 1 & $\begin{array}{l}\text { Open system, } \\
\text { continuous ring of } \\
\text { vascular bundles, } 4 \\
\text { extra vascular } \\
\text { bundles }\end{array}$ & I. pes-caprae \\
\hline Type 2 & $\begin{array}{l}\text { Open system, } \\
\text { continuous ring of } \\
\text { vascular bundles }\end{array}$ & C. inophyllum \\
\hline Type 3 & $\begin{array}{l}\text { Closed system, } \\
\text { continuous ring of } \\
\text { vascular bundles }\end{array}$ & H. tiliaceus \\
\hline Type 4 & $\begin{array}{l}\text { Open system, } \\
\text { continuous ring of } \\
\text { vascular bundles, } 2 \\
\text { extra vascular } \\
\text { bundles }\end{array}$ & S. jamaicensis \\
\hline
\end{tabular}

Table 3: Description of midrib vascular bundles for species studied

\begin{tabular}{|l|l|l|}
\hline Type of pattern & Description & Species \\
\hline Type 1 & $\begin{array}{l}\text { Open system, } \\
\text { continuous ring of } \\
\text { vascular bundles }\end{array}$ & I. pes-caprae \\
\hline Type 2 & $\begin{array}{l}\text { Open system, non - } \\
\text { continuous ring of } \\
\text { vascular bundles }\end{array}$ & C. inophyllum \\
\hline Type 3 & $\begin{array}{l}\text { Closed system, non- } \\
\text { continuous ring of } \\
\text { vascular bundles }\end{array}$ & H. tiliaceus \\
\hline Type 4 & $\begin{array}{l}\text { Open system, } \\
\text { continuous ring of } \\
\text { vascular bundles, } 2 \\
\text { extra vascular } \\
\text { bundles }\end{array}$ & S. jamaicensis \\
\hline
\end{tabular}

Dichotomous identification key for all the species studied is built based on combination of leaf anatomy and micromorphological characteristics. This dichotomous key can proof that leaf anatomy and micromorphology can be used for identification of species.

1.Homostomatic stomata, paracytic or diacytic, presence of cell inclusions, sinuous or straight to wavy anticlinal wall.............................................................. 2

1.Heterostomatic stomata, paracytic and anisocytic, absence of cell inclusions, straight to wavy anticlina wall................................................................... pes-caprae

2.Absence of trichomes, rounded guard cell pair, open-system vascular bundle, paracytic stomata, sinuous anticlinal wall................................................... inophyllum

2.Presence of trichomes, elliptic guard cell pair, open or closed-system vascular bundles, paracytic or diacytic, sinous or straight to wavy .................................................

3.Verrucate, flakes and granular coating of epidermis, closed-system vascular bundle, multicellular capitate glandular trichomes and stellate trichomes, straight to wavy anticlinal wall ....................................................................................... H. tiliaceus

3.Film layer, crust and granular coating of epidermis, open-system vascular bundle, peltate glandular trichomes and simple multicellular trichomes, sinuous anticlina wall ............................................................................. jamaicensis
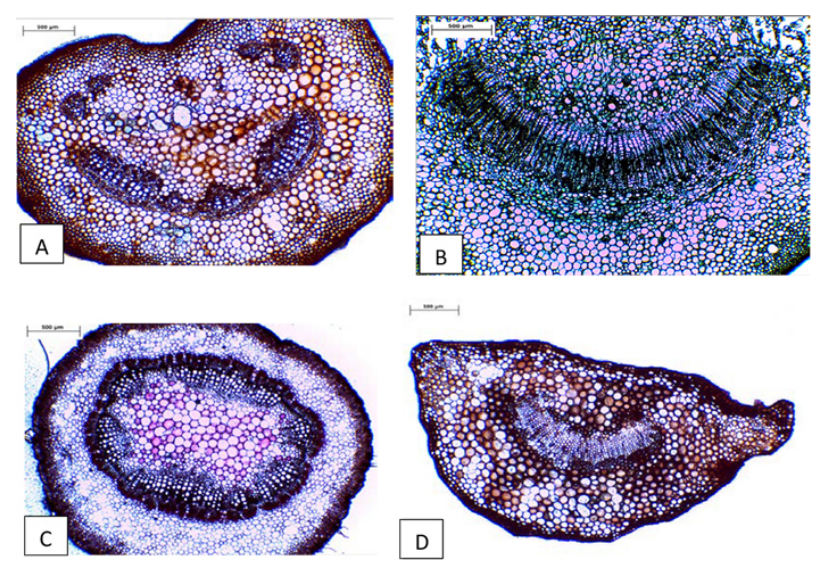

Figure 3: Vascular bundles of petiole; A) I. pes-caprae; B) C. inophyllum; C) H. tiliaceus; D) S. jamaicensis.
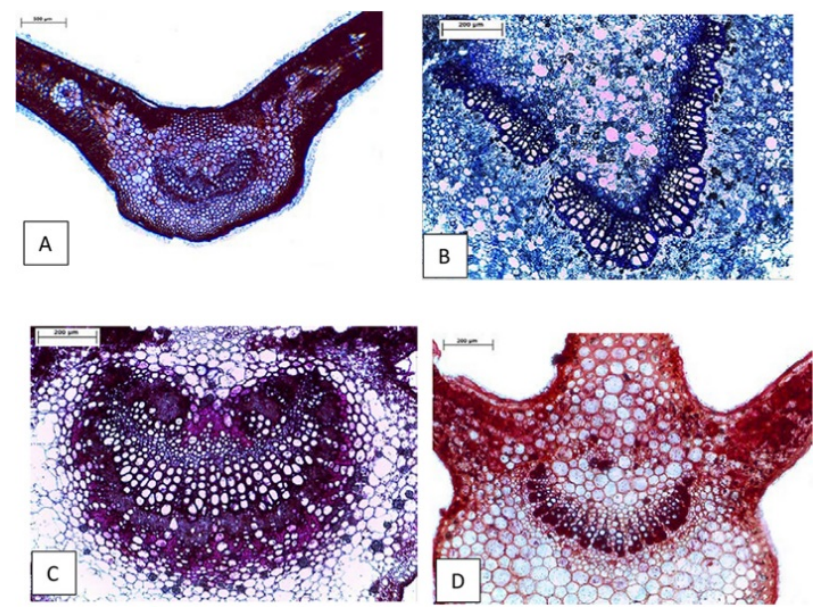

Figure 4: Vascular bundles of midrib; A) I. pes-caprae; B) C. inophyllum; C) H. tiliaceus; D) S. jamaicensis.

\section{CONCLUSION}

The result from this study showed that leaf anatomy and micromorphology can be used to identify plant species that grow along the coastal area. There are three common characteristics that could be identified between all the species studied. It was found that the presence of mucilage cells or canals, collenchyma and sclerenchyma cells are the similarities observed in four different species. This is perhaps they need 
to store water and withstand the strong wind at the coastal region. In conclusion, leaf anatomy and micromorphology characteristics are useful for identification of species in coastal area. It can be concluded that leaf anatomy and micromorphology characteristics are significantly contribute for the identification and classification of plant species along the coastal area in Malaysia and ASEAN countries as well.

\section{REFERENCES}

[1] Singh, V. 1981. Taxonomy of Angiosperms. New Delhi: Rastogi publications.

[2] Metcalfe, C.R., Chalk, L. 1950. Anatomy of the Dicotyledons. Volume. I. Oxford: Clarendon Press.

[3] Rudall, P. 2007. Anatomy of Flowering Plants: An Introduction to Structure and Development. (3rd ed.). Cambridge: Cambridge University Press.

[4] Dickison, W.C. 2000. Integrative Plant Anatomy. San Diego: Harcourt Academic Press.

[5] Steeves, T.A., Sawhney, V.K. 2017. Essential of Developmental Plant Anatomy., United States of America: Oxford University Press.

[6] Chan, H.T., Baba, S. 2009. Manual on Guidelines for Rehabilitation of Coastal Forests damaged by Natural Hazards in the Asia-Pacific Region. International Society for Mangrove Ecosystems (ISME) and International Tropical Timber Organization (ITTO), Pp. 4-6.

[7] John, W.H. 1908. The Comparative Leaf Structure of the Sand Dune Plants of Bermuda. Proceedings of the American Philosophical Society, 47 (188), 97-110.

[8] Metcalfe, C.R., Chalk, L. 1979. Anatomy of the Dicotyledons. Oxford: The Clarendon Press, 1, Pp. 100-105.

[9] Metcalfe, C.R., Chalk, L. 1950. Anatomy of the Dicotyledons. Oxford: Clarendon Press, 1

[10] Bakker, M.E., Gerritsen, A.F., Van Der Schaaf, P.J. 1992. Leaf anatomy of Cinnamomum Schaeffer (Lauraceae) with special reference to oil and mucilage cells. Blumea, 37, 1-30.

[11] Martins, F.M., Lima, J. F., Mascarenhas, S.A., Macedo, T.P. 2012. Secretory structures of Ipomoea asarifolia: anatomy and histochemistry. Brazilian Journal of Pharmacognosy, 22 (1), 13-20.

[12] Hassan, M.I., Nasser, A.A., Esraa, S.M., Abdul Nasser A.A. 2016. Morphological, epidermal and anatomical properties of Datura Linn. leaf in Sana'a city-Yemen and its taxonomical significance. Asian Journal of
Plant Science, 6 (4), 69-80.

[13] Okeke, C.U., Iroka, C.F., Izundu, A.I., Okereke, N.C., Onwuasoeze, C.I., Nyananyo, B. L. 2015. Comparative systematic leaf and petiole anatomical studies of the genus Stachytarpheta found in Awka Nigeria. Journal of Medicinal Plant Studies, 3 (4), 82-84.

[14] Noraini, T., Cutler, D.F. 2009. Leaf anatomical and micromorphological characters of some Malaysian Parashorea (Dipterocarpaceae). Journal of Tropical Forest Science, 21 (2), 156-167.

[15] Perveen, A., Abid, R., Fatima, R. 2007. Stomatal types of some dicots within flora of Karachi, Pakistan. Pakistan Journal of Botany, 39 (4), 1017 1023.

[16] Noor-Syaheera, M.Y., Noraini, T., Radhiah, A.K., Che-Nurul-Aini, C.A.C. 2015. Leaf anatomical characteristics of Avicennia L. and some selected taxa in Acanthaceae. Malayan Nature Journal, 67 (1), 81-94.

[17] Sivaranjani, R., Ramakrishnan, K., Bhuvaneswari, G. 2013. MorphoAnatomical and Preliminary Phytochemical Studies of The Leaf of Stachytarpheta jamaicensis (L) Vahl. International Journal of PharmTech Research, 5 (2), 577-582.

[18] Nurhanim, M.N., Noraini, T., Chung, R.C.K., Nurul-Aini, C.A.C., Ruzi, A.R. 2014. Taxonomic Value of Leaf Anatomical Characterisctics in Schoutenia Korth (Malvaceae subfam. Brownlowioideae). Sains Malaysiana, 43 (3), 331-338.

[19] Nurul-Aini, C.A.C., Noraini, T., Latiff, A., Amirul-Aiman, A.J., Ruzi, A.R., Idris, S. 2014. Taxonomical significance of leaf micromorphology in some selected taxa of Acanthaceae (Peninsular Malaysia). American Institute of Physics, 1614, 727-733.

[20] Noraini, T., Ruzi, A.R., Ismail, B.S., Ummu Hani, B., Salwa, S., Azi Azeyanty, J. 2016. Petiole vascular bundles and its taxonomic value in the tribe Dipterocarpaceae. Sains Malaysia, 45 (2), 247-253.

[21] Nurul-Aini, C.A.C., Noraini, T., Latiff, A., Chung, R.C.K., Nurhanim, M.N., Ruzi, A.R. 2013. Systematic significance of petiole anatomical characteristics in Microcos L. Malayan Nature Journal, 65 (2-3), 145-170.

[22] Ekeke, C., Mensah, S.I. 2015. Comparative anatomy of midrib and its significance in the taxonomy of the Family Asteraceae from Nigeria. Journal of Plant Science, 10 (5), 200-205.

[23] Nurul-Syahirah, M., Noraini, T., Latiff, A. 2016. Characterization of midrib vascular bundles of selected medicinal species in Rubiaceae. American Institute of Physics. 